Maria Tkocz, Arkadiusz Heder

Uniwersytet Śląski, Katowice

\title{
Działalność innowacyjna upadającej branży przemysłowej na przykładzie górnictwa węgla kamiennego
}

Jedną z głównych sił rozwojowych w XXI wieku są innowacje. Można je traktować jako proces polegający na przekształceniu istniejących możliwości w nowe idee i wprowadzenie ich do praktycznego zastosowania (Okoń-Horodyńska 2000). Można je uznać za twórcze zmiany w systemie społecznym, w strukturze gospodarczej, w technice oraz w przyrodzie (Świtalski 2005). Można przyjąć za R. Ayresem (1973), że są twórczością w sferze ekonomicznej bądź też pomyślną ekonomicznie eksploatacją nowych rozwiązań (Woźnicki i in. 2006). Innowacje stanowią podstawę postępu technicznego, a jednocześnie obejmują sferę społeczną, polityczną, duchową, zdrowia, konsumpcji oraz wiedzy. We współczesnych warunkach są efektem zbiorowych wysiłków i współdziałania wielu podmiotów (Bal-Woźniak 2009).

Teorię innowacji do nauk ekonomicznych wprowadził J.A Schumpeter w pracy opublikowanej w roku 1912, a wydanej w j. polskim w 1960. Sformułował on pięć przypadków innowacji: wytworzenie nowego produktu lub wprowadzenie na rynek towarów o nowych właściwościach, wprowadzenie nowej metody produkcji, otwarcie nowego rynku zbytu, zdobycie nowych źródeł surowców, przeprowadzenie nowej organizacji jakiegoś przemysłu, np. utworzenie monopolu lub jego likwidację (Pomykalski 2001). Działania innowacyjne stanowią zasadniczy element rozwoju dzisiejszego przemysłu, w którym coraz większą rolę odgrywa unowocześnianie zarówno w fazie wytwarzania, przez coraz bardziej efektywną produkcję dążącą do minimalizacji kosztów produkcji, zwiększanie jakości produktu finalnego, czy zwiększanie dochodów przedsiębiorstwa, ale również w sferze organizacyjnej, bezpieczeństwa pracy, oraz w ochronie środowiska i jego kształtowaniu, na które w obecnych czasach zwraca się coraz większą uwagę (Zioło 2009). Górnictwo węgla kamiennego jest branżą należącą do przemysłu tradycyjnego, którego szczytowy okres rozwoju w Polsce miał miejsce w gospodarce centralnie sterowanej. Węgiel kamienny pozostaje jednak ważnym surowcem energetycznym w wielu rozwijających się gospodarkach światowych jak np. Chiny czy Indie. Światowa Agencja Energii szacuje, że w 2030 roku potrzeba będzie 7 mld ton węgla kamiennego i brunatnego na potrzeby produkcji energii elektrycznej. Inne spojrzenie na rolę węgla kamiennego w energetyce ma Unia Europejska 
nakazująca Polsce ograniczenie produkcji energii elektrycznej na bazie tego surowca. W kontekście tych odmiennych tendencji sytuacja polskiego górnictwa jest szczególnie trudna. Nasuwa się pytanie jakie działania podejmuje resort górnictwa by sprostać tym zadaniom?

Celem artykułu jest przedstawienie działań innowacyjnych w górnictwie węgla kamiennego w Polsce. Ze względu na trudności w uzyskaniu potrzebnych materiałów źródłowych zakres pracy ograniczono do:

1. Innowacji w sferze zarządzania, czyli wdrażania nowych sposobów organizowania i zarządzania działalnością produkcyjną i usługową.

2. Innowacji produktowej, czyli wprowadzania na rynek produktu o lepszym działaniu.

3. Innowacji procesowej, czyli przyjęcia nowych lub znacząco ulepszonych metod produkcji albo dostarczania produktów.

4. Innowacji technologicznej obejmującej znaczące zmiany technologiczne w procesach produkcyjnych (Pomykalski 2001).

Jako materiał źródłowy wykorzystano informacje udostępnione przez Katowicki Holding Węglowy, Kompanię Węglową oraz raporty „Nowego Przemysłu”.

\section{GóRniCTWO WĘGLA KAMIENNEGo JAKO UPADAJĄCA BRANŻA PRZEMYSŁU W Polsce}

Wkroczenie Polski na drogę gospodarki rynkowej spowodowało istotne zmiany w funkcjonowaniu górnictwa węgla kamiennego. W gospodarce Polski Ludowej górnictwo było branżą wybitnie preferowaną a jego pozycja była jednoznacznie mocna. W gospodarce wolnorynkowej okazało się branżą z wieloma problemami związanymi głównie z nadmiernym wydobyciem, zatrudnieniem, wysokim kosztem eksploatacji oraz olbrzymią kwotą dotacji niezbędnej do jego dalszego funkcjonowania. W okresie 1989-2010 nastąpił spadek wydobycia o $57 \%$, ze $177 \mathrm{mln}$ ton do $76 \mathrm{mln}$ ton (ryc. 1), zatrudnienia o 73\%, z 415,7 tys. do 113 tys. (ryc. 2), liczby kopalń o 59\%, z 70 do 29 (ryc. 3). Spadek wydobycia spowodował systematyczny wzrost importu węgla (ryc. 4). Przedstawione pokrótce tendencje spadkowe w funkcjonowaniu górnictwa, szczególnie silnie widoczne w redukcji zatrudnienia, wymusiły konieczność wprowadzenia działań innowacyjnych umożliwiających konkurowanie branży na rynku polskim i światowym. 


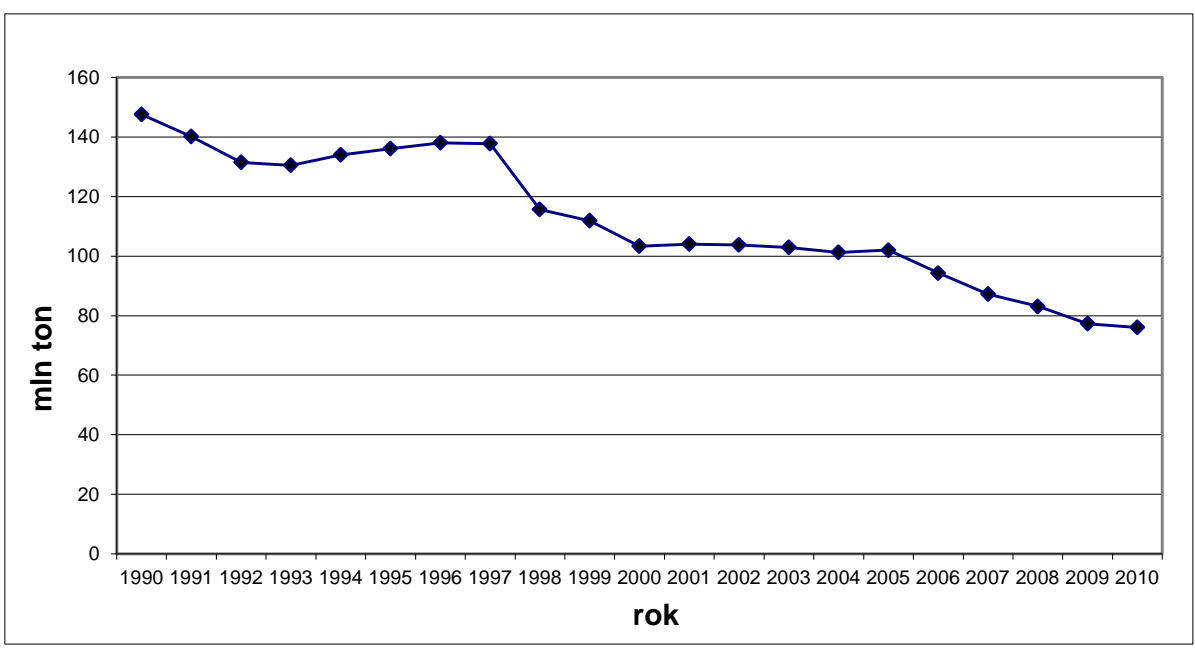

Ryc. 1. Wydobycie węgla kamiennego w Polsce

Źródło: roczniki statystyczne Ministerstwa Górnictwa

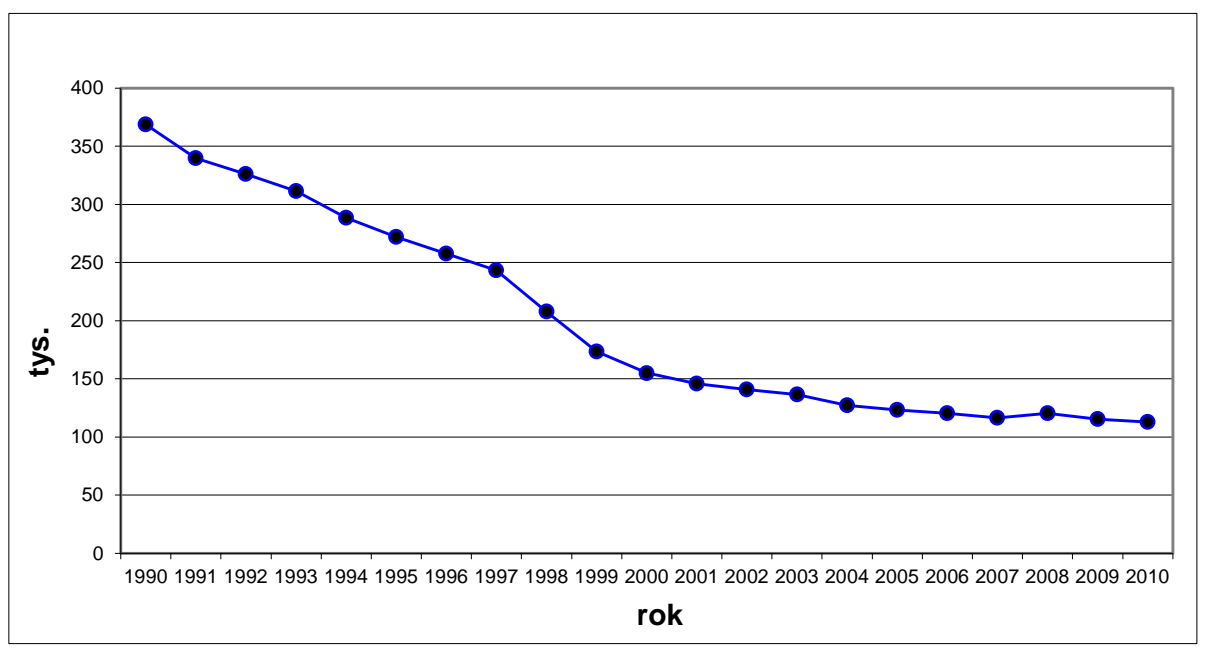

Ryc. 2. Zatrudnienie w górnictwie węgla kamiennego w Polsce

Źródło: roczniki statystyczne Ministerstwa Górnictwa i Energetyki, dane Ministerstwa Gospodarki 


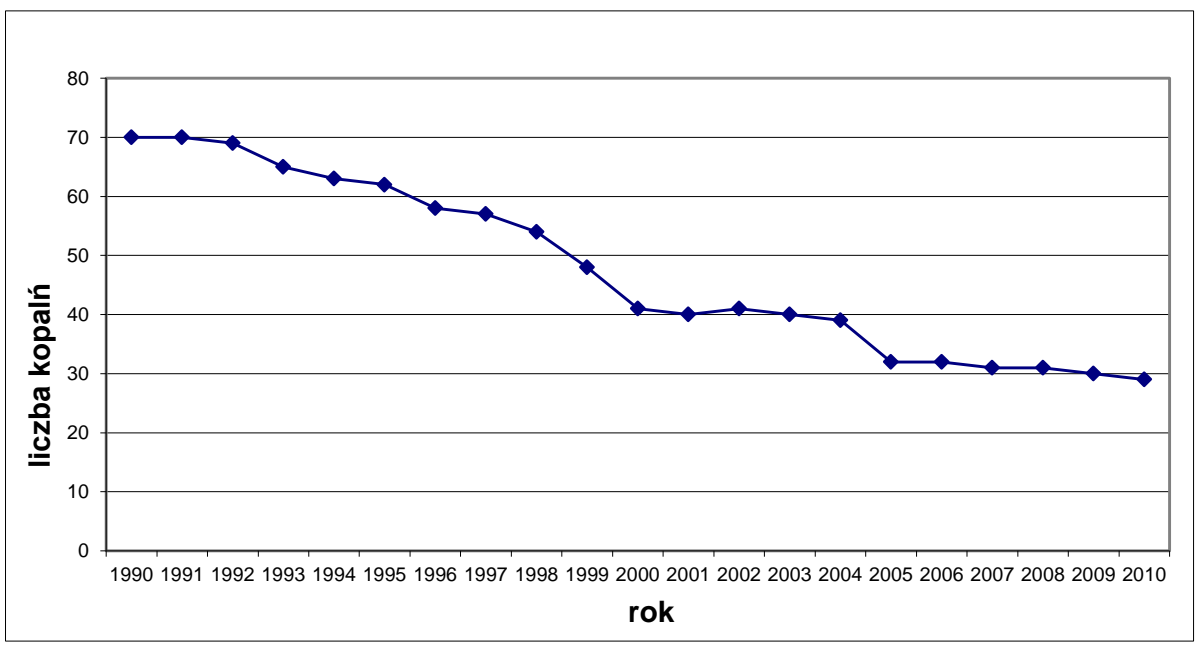

Ryc. 3. Liczba kopalń czynnych w górnictwie węgla kamiennego w Polsce

Źródło: podstawowe informacje dotyczące likwidacji kopalń. ARP o. Katowice, 2005, dane Ministerstwa Gospodarki

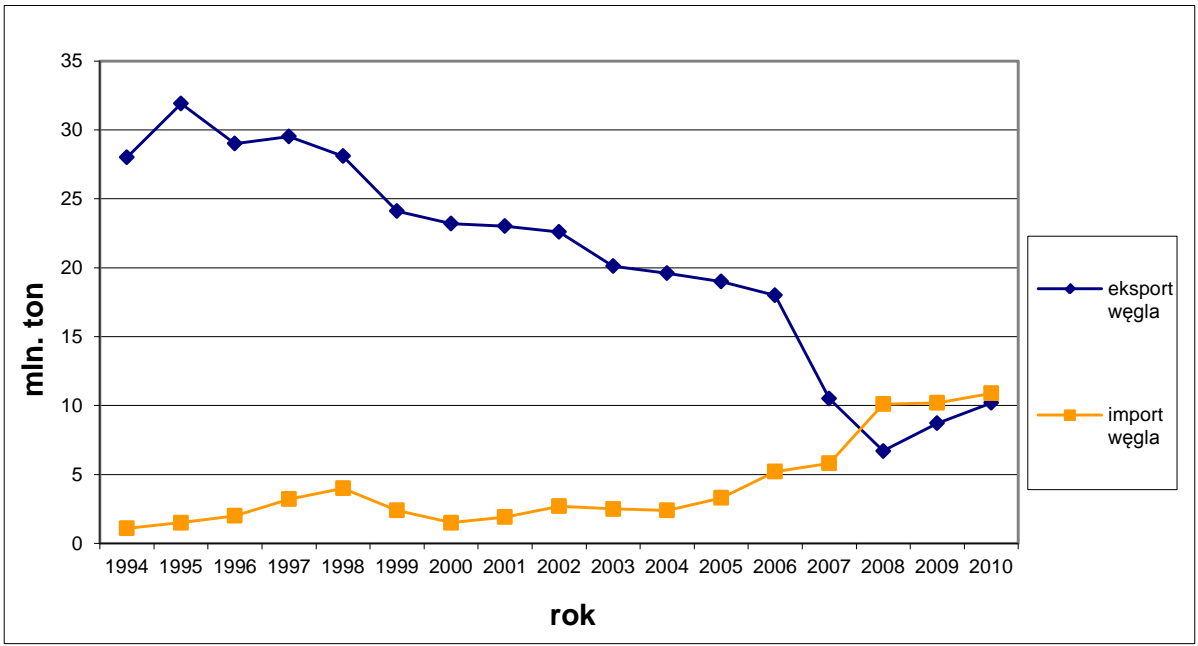

Ryc. 4. Eksport i import węgla kamiennego Polski

Źródło: informacja rządu w sprawie sytuacji w górnictwa węgla kamiennego 2007, dane Ministerstwa Gospodarki 
INNOWACJE W SFERZE ZARZĄDZANIA

Wprowadzenie gospodarki rynkowej zaowocowało istotnymi zmianami w sferze organizacyjno-własnościowej oraz zarządzania w górnictwie. W 1990 roku kopalnie węgla kamiennego uzyskały status przedsiębiorstw państwowych i pełną samodzielność. Okres funkcjonowania jako samodzielnych przedsiębiorstw trwał krótko, bowiem już w 1993 roku kopalnie przekształcono w jednoosobowo spółki Skarbu Państwa a następnie połączono w koncerny. Powołano 7 węglowych spółek akcyjnych, w tym $6 \mathrm{w}$ formie koncernu (Bytomska, Rudzka, Gliwicka, Nadwiślańska, Rybnicka, Jastrzębska) i jedną w formie holdingu (Katowicki Holding Węglowy). Kolejne zmiany organizacyjne nastąpiły w 2003 roku kiedy zlikwidowano spółki: Bytomską, Rudzką, Gliwicką, Nadwiślańską i Rybnicką, a w ich miejsce utworzono Kompanię Węglową z centrami wydobycia. Katowicki Holding Węglowy i Jastrzębska Spółka Węglowa nie zmieniły formy organizacyjnej (tab. 1). Od 1 stycznia 2012 roku w Kompanii Węglowej obowiązuje nowa struktura organizacyjna. Zlikwidowane zostały centra wydobycia, a dyrektorzy kopalń otrzymali większe kompetencje. W nowym modelu organizacyjnym dyrektor kopalni będzie odpowiadał za zarządzanie kopalnią, wydobycie oraz osiąganie planowych wskaźników efektywności. Zamierzeniem zmian organizacyjnych jest bardziej efektywne wykorzystanie złóż oraz majątku produkcyjnego kopalń.

Tab. 1. Spółki węglowe w górnictwie węgla kamiennego w $2011 \mathrm{r}$.

\begin{tabular}{|l|c|l|}
\hline \multicolumn{1}{|c|}{ Nazwa spółki węglowej } & Liczba kopalń & \multicolumn{1}{|c|}{ Nazwa kopalni } \\
\hline Kompania Węglowa & 15 & $\begin{array}{l}\text { Bielszowice, Bobrek-Centrum, Bolesław } \\
\text { Śmiały, Brzeszcze, Halemba-Wirek, } \\
\text { Chwałowice, Jankowice, Knurów- } \\
\text {-Szczygłowice, Marcel, Piast, Piekary, Pokój, } \\
\text { Rydułtowy-Anna, Sośnica-Makoszowy, } \\
\text { Ziemowit }\end{array}$ \\
\hline Jastrzębska Spółka Węglowa & 5 & $\begin{array}{l}\text { Borynia-Zofiówka, Budryk, Jas-Mos, } \\
\text { Krupiński, Pniówek }\end{array}$ \\
\hline Katowicki Holding Węglowy & 5 & $\begin{array}{l}\text { Murcki-Staszic, Mysłowice-Wesoła, } \\
\text { Wieczorek, Wujek, Kazimierz-Juliusz }\end{array}$ \\
\hline Południowy Koncern Węglowy & 2 & Sobieski, Janina \\
\hline Lubelski Węgiel Bogdanka & 1 & Bogdanka \\
\hline Prywatne & 1 & Siltech \\
\hline
\end{tabular}

Źródło: opracowanie własne na podstawie gornictwo.wnp.pl

Do działalności innowacyjnej w branży górniczej należy zaliczyć działania resortu związane z prywatyzacją poprzez sprzedaż zlikwidowanych kopalń prywatnym właścicielom. W ten sposób powstała prywatna kopalnia Siltech w Zabrzu, a kopalnię Dębieńsko, 
którą zamknięto 11 lat temu jako nierentowną, sprzedano koncernowi New World Resources Karbonia. Koncern ten w 2011 r. rozpoczął inwestycje zmierzające do uruchomienia kopalni i budowy nowych szybów. NRW uzyskał 50-letnią koncesję na wydobycie węgla, przyznaną w 2008 r. NRW planuje również wznowienie wydobycia węgla w nieczynnej kopalni Morcinek.

Innym przykładem innowacyjności organizacyjnej jest współpraca inwestycyjna branży górniczej z energetyką. Przykładem może być Południowy Koncern Węglowy w ramach którego funkcjonują dwie kopalnie „Sobieski” i „Janina”. Wchodzi on w skład grupy energetycznej „Tauron”, która skupia także 7 elektrowni i 2 elektrociepłownie, w tym elektrownię Jaworzno III, która jest ściśle powiązana dostawami węgla z kopalnią „Sobieski”. Grupa Tauron wzorem europejskich gigantów energetycznych utworzyła holding, składający się z powiązanych ze sobą koncernów: węglowego, wytwarzającego energię, dystrybucyjnego oraz zajmującego się nowoczesnymi technologiami. Tylko taka struktura ma szanse w zderzeniu z konkurencją zachodnich firm energetycznych. Daje także możliwość stabilizacji w zakresie eksploatacji węgla dla kopalń wchodzących w skład grupy.

Działalność innowacyjna w zakresie organizacyjnej to również poszukiwanie takich form działania, które byłyby nowym źródłem finansowania. Taką formą jest wprowadzenie spółek węglowych na giełdę papierów wartościowych. Pierwsza spółka węglowa notowana od 25 czerwca 2009 r. na warszawskiej Giełdzie Papierów Wartościowych to kopalnia Lubelski Węgiel Bogdanka SA, druga to Jastrzębska Spółka Węglowa notowana od 11 lipca 2011 roku.

Do działalności organizacyjnej o charakterze innowacyjnym można także zaliczyć poszukiwania nowych form sprzedaży węgla, zwłaszcza energetycznego. W ramach działalności marketingowej Katowicki Holding Węglowy i Kompania Węglowa zorganizowały na terenie Polski sieć dilerów (ryc. 5) sprzedających węgiel oraz rozlokowały składy węglowe (ryc. 6). KHW posiada także składy zagraniczne: w Austrii - 1, w Czechach - 3 oraz na Węgrzech - 1. Składy są lokowane blisko bocznic kolejowych, co ma się przyczynić do racjonalizacji kosztów transportu. Otwarcie sieci nowych składów na terenie całej Polski ma doprowadzić do tego, by cena węgla kształtowała się w różnych regionach kraju na zbliżonym poziomie. Dzięki uruchomieniu nowych placówek sprzedaży spółki węglowe chcą ograniczyć działania pośredników, którzy sprzedają węgiel po cenie wyższej o ok. 100 do 200 zł na tonie, windując marże transportowe. Dzięki składom węglowym cena węgla oferowanego na obszarach oddalonych od Górnego Śląska ma być zbliżona do ceny węgla przy bramie kopalni. Uruchamiając sieć nowych placówek sprzedaży spółki węglowe zamierzają stworzyć atrakcyjną ofertę nie tylko dla odbiorców indywidualnych, ale też między innymi dla ośrodków zdrowia, szkół czy przedszkoli. Wszystkie te instytucje znajdują się w gronie potencjalnych klientów (wnp.pl 2006). 


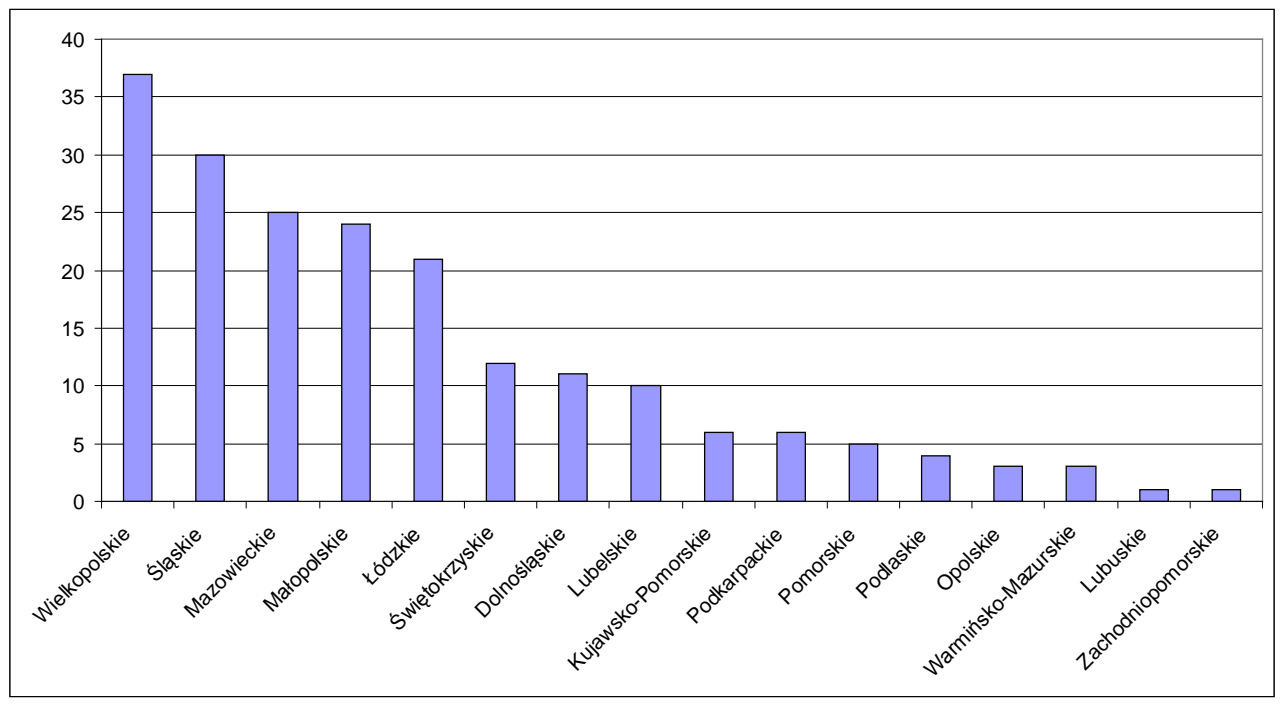

Ryc. 5. Liczba dilerów Katowickiego Holdingu Węglowego w poszczególnych województwach

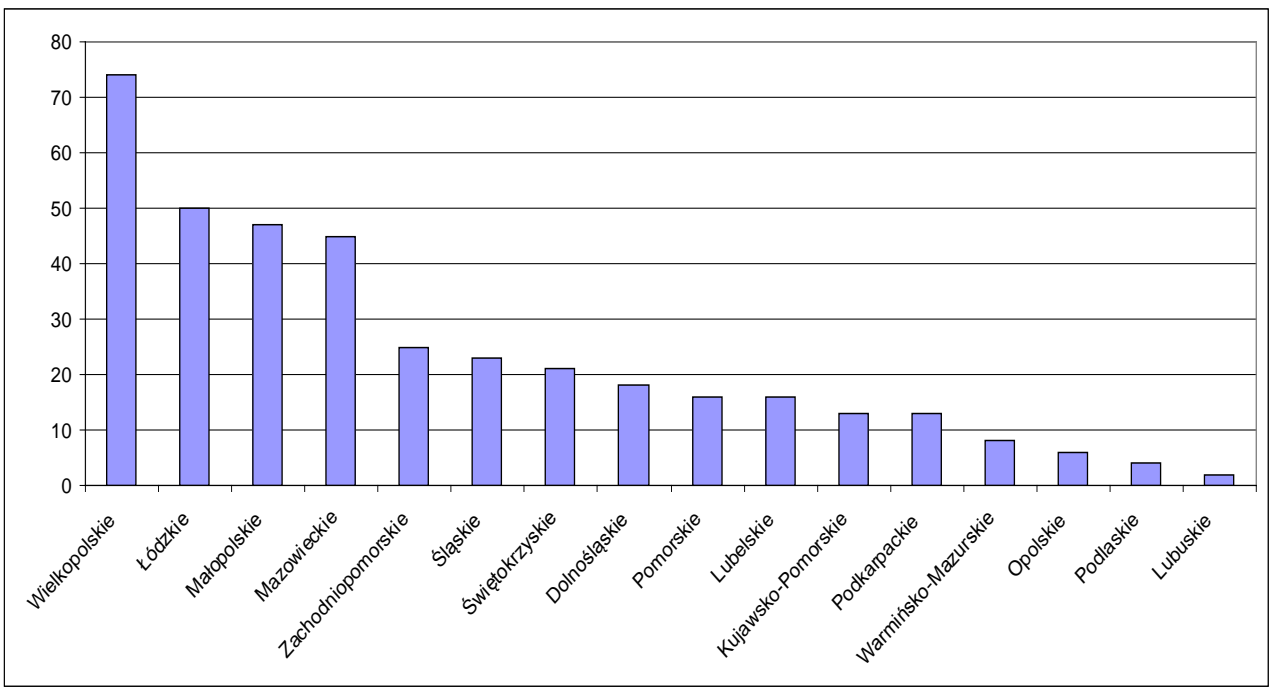

Ryc. 6. Liczba składów węgla Katowickiego Holdingu Węglowego w poszczególnych województwach 


\section{INNOWACYJNOŚĆ PRODUKCYJNA}

W trosce o ochronę środowiska, a przede wszystkim powietrza atmosferycznego, oraz w odpowiedzi na zapotrzebowanie rynku kopalnie udoskonalają technologię produkcji, tworząc nowatorskie ekologiczne produkty. Przykładem mogą być Kwalifikowane Paliwa Węglowe. Są to wysokokaloryczne, niskozasiarczone paliwa o powtarzalnych parametrach jakościowych produkowane na bazie węgla z wybranych kopalń Katowickiego Holdingu Węglowego S.A. Należą do nich: Ekoret - paliwo węglowe przeznaczone wyłącznie do spalania w nowoczesnych, niskoemisyjnych kotłach z paleniskami retortowymi oraz Eko-fins czyli paliwo węglowe o granulacji $0 \div 30(35) \mathrm{mm}$ przeznaczone wyłącznie do niskoemisyjnych kotłów z paleniskami retortowymi lub rusztowymi z ciągłym podawaniem paliwa.

Efektem innowacyjności produkcyjnej jest również produkowany w KWK „Piast” węgiel o nazwie „Retopal” - ekogroszek o uziarnieniu 6-20 mm, sprzedawany luzem, a także paczkowany w worki po $25 \mathrm{~kg}$. Produkt ten powstaje z wyselekcjonowanych węgli o najlepszych parametrach, jest źródłem czystej energii, gdyż spalany jest w niskoemisyjnych kotłach retortowych. Spełnia on kryteria znaku bezpieczeństwa ekologicznego, co zostało potwierdzone przez Instytut Chemicznej Przeróbki Węgla dla kotłów Eko-Leg produkowanych przez Firmę „Legal”. Służy również jako paliwo do kotłów fluidalnych w nowoczesnych instalacjach w energetyce. Zastosowano go w elektrowni „Siersza” i elektrociepłowni „Bielsko”. W 2005 roku uruchomiono w KWK „Piast” automatyczną linię paczkowania produkowanego węgla „Retopal”. Drugim typem ekologicznych paliw węglowych jest „Pieklorz” - ekogroszek produkowany w Zakładzie Górniczym „Piekary”, KWK „Bobrek-Centrum”, oraz w KWK „Chwałowice”. Podobnie jak „Retopal” węgiel ten jest stosowany do wszystkich rodzajów kotłów z automatycznymi palnikami retortowymi i rusztowymi (Kompania Węglowa 2008).

Do nowatorskich produktów ekologicznych można zaliczyć także koncentraty miałowe. Miał charakteryzuje się obniżoną zawartością siarki (poniżej 1\%) i dobrą wartością opałową $23000-25000 \mathrm{~kJ} / \mathrm{kg}$. Niska zawartość popiołu (poniżej 10\%), wraz z pozostałymi parametrami jakościowymi, stanowi o walorach tego produktu jako paliwa do ekologicznych niskoemisyjnych kotłów w gospodarstwach domowych (XXX-lecie KWK „Piast” 2005).

\section{INNOWACJE PROCESOWE}

Wyzwaniem współczesnego przemysłu wydobywczego jest konsekwentne zwiększanie efektywności wydobycia przy jednoczesnym zapewnieniu wzrostu bezpieczeństwa pracy górników. Jest to także cel polskiego górnictwa, którego przyszłością jest stosowanie systemów wydobywczych zarządzanych z powierzchni kopalni (Bednarz 2011). W tym zakresie konieczna jest współpraca kopalń z firmami produkującymi nowoczesne maszyny i urządzenia dla górnictwa.

W miarę postępu eksploatacji kolejnych pokładów wydobywczych konieczne staje się sięganie do głębszych i bardziej skomplikowanych geologicznie zasobów węgla. Wydobycie odbywa się w coraz trudniejszych warunkach górniczych, powodując tym samym koniecz- 
ność zmagania się z większymi zagrożeniami dla osób pracujących pod ziemią. Konieczne staje się umożliwienie wykrywania z odpowiednim wyprzedzeniem stanów przedawaryjnych i ograniczanie czasu przebywania górników w miejscach niebezpiecznych. Jednocześnie, aby zapewnić konkurencyjność polskich kopalń, konieczne jest zapewnienie efektywności wydobycia: nie tylko przez wzrost mocy maszyn górniczych, ale także dzięki ograniczaniu kosztownego czasu przestoju spowodowanego awariami sprzętu (Tumidajski i in. 2008). Można to osiągnąć dzięki łączeniu pracy ciężkiego, wysoko wydajnego sprzętu górniczego z inteligentnymi rozwiązaniami informatycznymi. Grupa kapitałowa „Famur” podjęła to wyzwanie i wprowadziła na rynek pionierski kompleks służący do wydobywania węgla z niskich pokładów, nadzorowany online z powierzchni kopalni. Kompleks FL 12/18 jest pierwszym zespołem maszyn górniczych wykonanym w całości w standardzie e-kopalnia-czyli wyposażonym w pełną diagnostykę i monitoring wszystkich istotnych parametrów oraz umożliwiającym transmisję tych danych na powierzchnię. Od kwietnia 2011 roku system wykorzystywany jest w KWK Murcki-Staszic, należącej do Katowickiego Holdingu Węglowego. Jest to innowacyjne na skalę światową rozwiązanie technologiczne, pozwalające wydajnie wydobywać niskie pokłady węgla. Niewielkie rozmiary w porównaniu do tradycyjnych kompleksów pozwalają na dotarcie do złóż węgla. E-kompleks FL 12/18 łączy pracę zespołu tych maszyn dla górnictwa $\mathrm{z}$ systemami informatycznymi wchodzącymi w skład systemu e-kopalnia (Bednarz 2011).

Innym podobnym przykładem zastosowania nowych rozwiązań produkcyjnych w kopalniach węgla kamiennego jest wdrożony, również przez Grupę Famur, w kopalni Bielszowice bezprzewodowy system monitorujący „Famac RSPC”. Jest to trzecia polska kopalnia wyposażona w to rozwiązanie. Wcześniej ten system został zainstalowany w kopalniach „Budryk” i „Marcel”. To innowacyjne rozwiązanie stanowi przełom w monitorowaniu prac wydobywczych. Istotnie wpływa na zwiększenie bezpieczeństwa pracy górników oraz optymalną eksploatację obudowy zmechanizowanej. Wchodzi w skład systemu e-kopalnia, służącego do nadzorowania online procesu wydobycia węgla. Dzięki gromadzonym informacjom, system umożliwia prawidłowe kierowanie stropem eksploatowanej ściany. Dzięki strukturze bezprzewodowej „Famac RSPC” jest szybki w montażu oraz tani w utrzymaniu. Uszkodzenia mechaniczne pojedynczych elementów podpór obudów ścianowych są szybko identyfikowane $\mathrm{i}$ - co szczególnie istotne - nie powodują przerwania ciągłości transmisji danych do komputera lokalnego i dalej na powierzchnię kopalni (www.gornictwo.wnp.pl 2010).

Jednym $\mathrm{z}$ elementów innowacyjności $\mathrm{w}$ działalności produkcyjnej $\mathrm{w}$ górnictwie jest również rozpoczęcie prac związanych z wykorzystaniem metanu. W 2012 roku w kopalni „Brzeszcze” należącej do Kompanii Węglowej ruszy pilotażowa instalacja do spalania nisko stężonego metanu. Firma zamierza współpracować w tej sprawie z Instytutem Inżynierii Chemicznej Polskiej Akademii Nauk. Metan - bezbarwny i bezwonny gaz towarzyszący złożom węgla - obecny jest w większości polskich kopalń. Uwalnianie się tego gazu to naturalne zjawisko w górnictwie. Część metanu, ujmowana w instalacjach odmetanowania, jest wykorzystywana energetycznie, pozostała część trafia do atmosfery poprzez kopalnianą wentylację. W niektórych kopalniach - przede wszystkim w Jastrzębskiej Spółce Węglowej, ale także w Kompanii Węglowej (Knurów-Szczygłowice, Sośnica-Makoszowy, Marcel) i w Katowickim Holdingu Węglowym - metan wykorzystywany jest do produkcji ciepła i prądu. Nie zawsze jest to jednak możliwe, bo do spalania gaz ten musi być odpowiednio stężony. Nowa metoda wykorzystania metanu nosząca nazwę ,rewersyjnego spalania nisko 
stężonego metanu" opracowana została w gliwickim instytucie PAN. Dzięki temu osiągane są korzyści energetyczne, a jednocześnie następuje utylizacja tego gazu z kopalnianej wentylacji. „W tym projekcie, obok aspektów ekologicznego i ekonomicznego, niezwykle istotna jest poprawa bezpieczeństwa pracy. Zagospodarowanie metanu - wykorzystanie go do celów przemysłowych - poprawia warunki pracy w kopalniach i jest jednocześnie przykładem innowacyjności i wykorzystania polskiej myśli naukowej w przemyśle.

Z danych Wyższego Urzędu Górniczego i Głównego Instytutu Górnictwa wynika, że zmniejszenie produkcji węgla w ostatnich kilkunastu latach nie spowodowało znaczącego spadku ilości metanu, wydzielającego się z węglowych pokładów. Przeciwnie, zwiększa się liczba kopalń, gdzie występuje zagrożenie metanowe, co wiąże się z eksploatowaniem coraz niższych pokładów, poniżej 500 metrów. Średnia głębokość eksploatacji węgla rośnie o ok. 8-10 m rocznie. Według WUG, w ostatnich latach w polskich kopalniach węgla kamiennego wydzielało się ok. $830-880 \mathrm{mln} \mathrm{m}^{3}$ metanu, czyli średnio ponad 1,6 tys. $\mathrm{m}^{3}$ na minutę; w ubiegłym roku było to $834,86 \mathrm{mln}^{3}$. Z tego około jedna trzecia trafiła do instalacji odmetanowania. Większość metanu z kopalń jest wyprowadzona do atmosfery drogą wentylacyjną, szkodząc klimatowi, bo potencjał cieplarniany metanu jest 21-krotnie większy niż dwutlenku węgla. Obecnie efektywność wykorzystania ujętego metanu zbliżona jest do 60\%. Instalacje odmetanowania działają w 20 kopalniach (Polska Agencja Prasowa 2011).

Działania innowacyjne to również uruchomienie nowych obszarów eksploatacji węgla nowymi metodami. Przykładem może być kopalnia Bogdanka. W 2011 roku rozpoczęto tam próbny rozruch ściany wydobywczej w Polu Stefanów nowoczesnym kompleksem strugowym, o bardzo wysokiej wydajności, sięgającej blisko 17 tys. ton urobku na dobę. Uruchomienie szybu wydobywczego w Stefanowie i rozruch ściany strugowej pozwolił spółce na przeprowadzenie pod pełnym obciążeniem rozruchu tzw. estakady, naziemnego układu transportu i podstawy urobku z pola Stefanów do Bogdanki.

\section{INNOWACYJNOŚĆ TECHNOLOGICZNA W OCHRONIE I KSZTAŁTOWANIU ŚRODOWISKA}

W trosce o zminimalizowanie wpływu wód dołowych na środowisko kopalnie wykonują szereg prac, które znacznie zmniejszają ilość odprowadzanych wód, ich uciążliwość i negatywne oddziaływanie na środowisko. Działania ograniczające uciążliwość wód to inwestycje wykonane bezpośrednio na dole kopalni. Ich celem jest redukcja zanieczyszczeń promieniotwórczych i mechanicznych przed odpompowaniem i zrzutem wód do rzeki. W latach 1995-1999 na poziomie wydobywczym 650 m w Kopalni „Piast” w Bieruniu została wybudowana dla kopalń „Piast” i „Ziemowit” instalacja do usuwania z wód izotopowych radu $226 \mathrm{Ra}$ i radu $228 \mathrm{Ra}$. Jest to pierwsza na świecie tego typu instalacja wybudowana w górnictwie nieuranowym. Innym przykładem jest wybudowanie na poziomie $500 \mathrm{~m}$ instalacji do strącania zanieczyszczeń mechanicznych niesionych z wodą z zastosowaniem środków chemicznych.

Kontynuacją działań mających na celu zminimalizowanie negatywnego wpływu wód dołowych z KWK „Piast” na środowisko jest realizacja zadań wynikających z zainicjowanego „Programu działań przedsięwzięć proekologicznych związanych z wodami zasolonymi na lata 2000-2010", służącego ochronie hydrotechnicznej rzeki Wisły przed nadmiernym 
zasoleniem wodami kopalnianymi. Przedsięwzięcie wykorzystuje możliwości zastosowania hydrotechnicznej metody i kontrolowanego zrzutu wód do Wisły. Ta proekologiczna inwestycja jest najlepszym i nowatorskim rozwiązaniem, wykorzystującym wyrobiska górnicze likwidowanego Ruchu II KWK „Piast” jako zbiornik retencyjno-dozujący wód słonych i dającym możliwości kontrolowanego ich zrzutu do wód powierzchniowych.

\section{WYBRANE PRZYKŁADY REZULTATÓW DZIAŁALNOŚCI INNOWACYJNEJ}

Przedstawione powyżej przejawy działalności innowacyjnej w górnictwie węgla kamiennego można będzie w pełni ocenić dopiero z perspektywy dłuższego czasu. Aktualnie można stwierdzić, że innowacja w sferze zarządzania, jaką było wprowadzenie Kopalni Bogdanka oraz Jastrzębskiej Spółki Węglowej na Giełdę Papierów Wartościowych, umożliwiła przeprowadzenie nowych inwestycji w tych podmiotach, zwiększających efektywność produkcji. Przykładem może być zakup gigantycznego struga węglowego za kwotę $160 \mathrm{mln}$ zł, dzięki któremu górnikom z Bogdanki udało się wydobyć 23 tys. ton węgla w ciągu doby, co jest rekordem w skali światowej. W związku z osiągniętym rezultatem kopalnia zamówiła drugi strug. Inwestycje w Kopalni Bogdanka zaowocowały wzrostem wydobycia do wielkości 5,8 mln ton w 2011 r. (www.lw.com.pl). Pozytywnym rezultatem wprowadzenia spółek na giełdę mogą być dobre wyniki finansowe oraz stabilizacja sprzedaży krajowej na poziomie ok. $11 \mathrm{mln}$ ton w JSW, a także wzrost zysku na akcję w tej spółce z 13,36 zł w 2010 r. do 18,43 zł w 2011 r. (www.jsw.pl). Pozytywne rezultaty zachęciły Ministerstwo Gospodarki do przedstawienia planów prywatyzacji pozostałych spółek węglowych poprzez giełdę. W roku 2012 na giełdzie ma zadebiutować Węglokoks zajmujący się sprzedażą węgla, a w 2014 Kompania Węglowa. Wyrazem podjętych działań innowacyjnych w zakresie ochrony środowiska może być „Ekolaur” przyznany Katowickiemu Holdingowi Węglowemu przez Polską Izbę Ekologii. Ze względu na tajemnicę handlową trudno oceniać rezultaty sprzedaży węglowych produktów ekologicznych typu „ekogroszek”. Można jedynie stwierdzić, na podstawie wywiadów z mieszkańcami woj. śląskiego, że jego użycie do ogrzewania domów jest konkurencyjne do gazu ziemnego. Przedstawiając rezultaty działalności innowacyjnej należy dodać, że w roku 2011 spółki węglowe uzyskały dodatni wynik finansowy netto, co pośrednio wskazuje na pozytywne efekty. Działania związane z ochroną środowiska możemy zaobserwować analizując m.in. zmiany emisji $\mathrm{CO}_{2}$ na tle innych krajów. Polska pomiędzy 1990 a 2005 rokiem o 18\% zmniejszyła emisję $\mathrm{CO}_{2}$, jednak nie jest to największa wartość wśród krajów Unii Europejskiej. Osiem krajów w tym okresie zmniejszyło emisję $\mathrm{CO}_{2}$ o ponad 20\% m.in. Łotwa, Litwa, Rumunia, Słowacja (Barchański 2009). Kraje rozwijające się wciąż mają znacznie mniejszy wskaźnik emisji $\mathrm{CO}_{2}$ na mieszkańca niż kraje Unii Europejskiej. Chiny, które są największym emitentem $\mathrm{CO}_{2}$ na świecie, na głowę mieszkańca wyemitowały w 2009 r. 5,13 tony a Indie, trzeci co do wielkości emitent, zaledwie 1,37 tony. W tym samym czasie średnia dla mieszkańców UE wyniosła 7,15 tony $\mathrm{CO}_{2}$. Statystyczny Polak wyemitował w 2009 r. nieznacznie więcej $\mathrm{CO}_{2}$, bo 7,52 tony. (www.energetyka.wnp. pl). Pokazuje to nadal wysoki poziom emisji $\mathrm{CO}_{2}$ przez Polskę. Przyczyną takiego stanu jest jeden z największych udziałów węgla $(94,5 \%)$ w produkcji energii elektrycznej w Polsce, wśród wszystkich krajów świata, przez co wszelkie formy innowacyjne nie przyczyniają się 
do aż tak dużego zmniejszenia emisji $\mathrm{CO}_{2}$ (Barchański 2009). Alternatywną możliwością zmniejszenia emisji $\mathrm{CO}_{2}$ jest produkcja energii elektrycznej z odnawialnych źródeł, których udział w produkcji energii w Polsce jest wciąż niewielki.

\section{UWAGI KOŃCOWE}

W artykule skoncentrowano się na działaniach innowacyjnych górnictwa węgla kamiennego w sferze organizacyjnej, produktowej, procesowej i technologicznej i stwierdzono, że mimo tendencji spadkowej w dziedzinie produkcji, w spółkach i kopalniach podejmowane są działania zmierzające do zahamowania procesu całkowitego upadku branży, jej unowocześnienia, zwłaszcza w zakresie eksploatacji, przy zastosowaniu wydajnych i zarazem nowoczesnych maszyn i urządzeń oraz udoskonalania technologii produkcji i tworzenia nowatorskich a jednocześnie ekologicznych produktów. Działania innowacyjne stosowane są również $\mathrm{w}$ zakresie ochrony środowiska a także $\mathrm{w}$ działalności marketingowej. W ten sposób górnictwo stara się sprostać konkurencji międzynarodowej oraz z innymi surowcami energetycznymi. Tworzenie grup kapitałowych z firmami energetycznymi stwarza możliwości stabilizacji wydobycia węgla, a funkcjonowanie na giełdzie papierów wartościowych daje dodatkowe korzyści finansowe.

\section{Literatura}

Ayres R., 1973, Prognozowanie rozwoju techniki i planowanie dlugookresowe, Państwowe Wydawnictwo Ekonomiczne, Warszawa.

Barchański B., 2009, Czy emisja antropogennego $\mathrm{CO}_{2}$ może mieć wpływ na górnictwo węgla w Polsce?, [w:] J. Kicki (red.), Materiaty Szkoty Eksploatacji Podziemnej 2009, Instytut Gospodarki Surowcami Mineralnymi i Energią Polskiej Akademii Nauk, Akademia Górniczo-Hutnicza, Katedra Górnictwa Podziemnego, Kraków, Wydawnictwo IGSMiE s. 455-471.

Bednarz R., 2011, Nowe technologie zwiększają bezpieczeństwo i efektywność wydobycia, „Magazyn Przemysłowy", nr 7-8.

Kompania Węglowa, gazeta firmowa, listopad 2008, Nowa era ogrzewania weglowego, Katowice.

Okoń-Horodyńska E., 2000, Narodowy system innowacji w Polsce. W kierunku podejścia sieciowego, [w:] Proces dostosowania gospodarki polskiej do kryteriów członkowskich Unii Europejskiej, Wydawnictwo AE, MWES w Tarnowie, Kraków-Tarnów.

Pomykalski A., 2001, Zarzadzanie innowacjami, PWN, Warszawa-Lódź.

Schumpeter J.A., 1960, Teoria rozwoju gospodarczego, PWN, Warszawa.

Świtalski W., 2005, Innowacje i konkurencyjność, Wydawnictwa Uniwersytetu Warszawskiego, Warszawa.

Tumidajski T., Gawenda T., Niedoba T., Saramak D., 2008, Kierunki zmian technologii przeróbki węgla kamiennego w Polsce, [w:] Gospodarka surowcami mineralnymi, t. 24, z. 1/2.

Woźnicki J., Dominik W., Sulejewicz A., Włosiński W., 2006, Określenie istoty pojęć: innowacji i innowacyjności, ze wskazaniem aktualnych uwarunkowań i odniesień do polityki proinnowacyjnej - podejście interdyscyplinarne, Krajowa Izba Gospodarcza, s. 8-11, 46.

Zioło Z., 2009, Rola przemystu w procesie ksztattowania społeczeństwa informacyjnego, Prace Komisji Geografii Przemysłu Polskiego Towarzystwa Geograficznego, nr 13, Warszawa-Kraków, s. 11-20. 
Zespół KWK „Piast” (red.), XXX lat Kopalnia Węgla Kamiennego Piast 1975-2005, s. 16, 160-164.

\section{Materialy prasowe, strony internetowe}

Nauka w Polsce, Polska Agencja Prasowa, 2011, „Wkrótce pilotażowy projekt spalania metanu”, www.naukawpolsce.pap.pl

Polska Agencja Prasowa, 2011, „Powstał klaster na rzecz innowacji w górnictwie”, www.wiadomosci. onet.pl

Wirtualny Nowy Przemysł, Serwis Górnictwo, 2010, „Famur wprowadza innowacje w kopalni Bielszowice", www.gornictwo.wnp.pl

Wirtualny Nowy Przemysł, Serwis Górnictwo, 2011, „NWR rusza z budową kopalni Dębieńsko”, www.wnp.pl

Wirtualny Nowy Przemysł, Serwis Energetyka, 2012, „Świat zwiększy emisję $\mathrm{CO}_{2}$ ”, www.wnp.pl

www.jsw.pl

www.lw.com.pl

\section{Innovative activities in a failing industrial sector on the example of the coal mining industry}

The coal mining industry in Poland belongs to the branches of industry currently breaking down. It is expressed by the liquidation of mines, whose number in 1989 equalled 70, while in 2010 - only 29; it is also visible in the steady decrease of coal extraction, from 177 million tonnes in 1989 to 77 million tonnes in 2009, whereas employment dropped from 415.7 thousand to 112 thousand, respectively. The decrease in extraction is connected with the process of transformation of the Polish economy and the necessity to adapt to the requirements imposed by the European Union, which required Poland to limit its production of electrical energy from coal. In this context, the situation of the coal mining industry is especially difficult. A question arises, what activities the department of mining has been undertaking in order to cope with these challenges. The article concentrates on innovative activities conducted by the mining industry. They have been presented in their organizational and technological spheres, including the main businesses functioning in the trade, namely Kompania Węglowa, consisting of 15 mines, Katowicki Holding Węglowy, comprising 4 mines, and Jastrzębska Spółka Węglowa, which consists of 5 mines, as well as the remaining mines functioning independently or within structures of other concerns. Innovative activities in the scope of branch management and organization of sales are described. Innovation in terms of technology consists in the introduction of new products, implementation of modern machinery and equipment for exploitation, as well as the monitoring of coal extraction and minimizing the negative impact on the environment.

Prof. UŚ. dr hab. Maria Tkocz

Uniwersytet Śląski, Katowice

Katedra Geografii Ekonomicznej

Zakład Gospodarki Przestrzennej

e-mail: Maria.tkocz@us.edu.pl

Mgr Arkadiusz Heder

Uniwersytet Śląski

Katedra Geografii Ekonomicznej

e-mail: Arekheder1987@gmail.com 